\title{
Eventful Non-Events: Distinguishing an Event from a Non-Event in Event Studies
}

\author{
Vivek Kumar $^{1 *}$, Arpita Srivastava ${ }^{2}$ \\ ${ }^{1}$ Indian Institute of Management, Kashipur, India \\ ${ }^{2}$ XLRI, Jamshedpur, India \\ Email: *vivek.kumar@iimkashipur.ac.in
}

How to cite this paper: Kumar, V. and Srivastava, A. (2017) Eventful Non-Events: Distinguishing an Event from a Non-Event in Event Studies. Theoretical Economics Letters, 7, 1067-1080. https://doi.org/10.4236/tel.2017.75072

Received: April 26, 2017

Accepted: June 28, 2017

Published: July 1, 2017

Copyright ( 92017 by authors and Scientific Research Publishing Inc. This work is licensed under the Creative Commons Attribution International License (CC BY 4.0).

http://creativecommons.org/licenses/by/4.0/

\begin{abstract}
Not all interesting events can be subjected to event studies. In this note, we take the example of event studies related corporate political activity to point out some events which though interesting cannot be used for event studies. Event studies in corporate political activity literature study stock market reaction to events such as election results, political parties suddenly coming into power, and ex-employees of a firm getting political positions. I assert that inference drawn in such studies is tautological. I point out an implicit assumption of event studies being violated in these studies. Event studies in this area not suffering from this problem are also pointed out.
\end{abstract}

\section{Keywords}

Event Study Methodology, Tautology, Corporate Political Activity

\section{Introduction}

Whether corporate political activity (CPA) adds value to a firm or not is an unsettled area of inquiry in strategy, finance and economics literature. While Bunkanwanicha \& Wiwattanakantang [1], Claessens, Feijen, \& Laeven [2], Faccio [3], Fisman [4], Goldman, Rocholl, \& Jongil So [5], Hillman, Zardkoohi, \& Bierman [6], and Jayachandran [7] find positive impact of CPA on firm performance, Aggarwal, Meschke, \& Wang [8], Ansolabehere, De Figueiredo, \& Snyder Jr. [9], Faccio [10], Hadani \& Schuler [11] Hersch, Netter, \& Pope [12], Hillman [13], Okhmatovskiy [14], and Siegel [15] find neutral or negative effect of $\mathrm{CPA}$ on firm performance. The difference in the two sets of studies does not end here. As can be seen from Table 1, all studies in the first set employ event study analysis while none in the second set do so, with the exception of Cooper, Gulen, \& Ovtchinnikov [16], who find positive impact of CPA on firm performance without using event study methodology. Is use of event study method the reason 
Table 1. Empirical studies testing the effect of political connections on firm value. RoA is return on assets, RoS is return on sales.

\begin{tabular}{|c|c|c|c|}
\hline Paper & Event Study? & Description & Result \\
\hline $\begin{array}{l}\text { Hadani and } \\
\text { Schuler [11] }\end{array}$ & No & $\begin{array}{l}\text { Firm market value and RoS regressed against political } \\
\text { contributions and board political connections }\end{array}$ & $\begin{array}{l}\text { Negative effect on market value for } \\
\text { both political contributions and board } \\
\text { political connections. No result for RoS. }\end{array}$ \\
\hline Okhmatovskiy [15] & No & $\begin{array}{l}\text { RoA regressed against government ownership, } \\
\text { and government directors. }\end{array}$ & No effect \\
\hline Faccio $[10]$ & No & RoA regressed against political connections. & $\begin{array}{l}\text { Connected firms have lower RoA } \\
\text { and market to book ratio. }\end{array}$ \\
\hline $\begin{array}{l}\text { Hersch, Netter, } \\
\text { and Pope [12] }\end{array}$ & No & $\begin{array}{l}\text { Tobin's Q regressed against political contributions, } \\
\text { lobbying expenditure, and sum of the two. }\end{array}$ & No effect \\
\hline Hillman [13] & No & $\begin{array}{l}\text { Effect of politicians on board on market } \\
\text { capitalization, market to book ratio, RoA and RoS. }\end{array}$ & $\begin{array}{l}\text { Positive for market cap and market } \\
\text { to book ratio, neutral for RoA, RoS }\end{array}$ \\
\hline $\begin{array}{l}\text { Cooper, Gulen, and } \\
\text { Ovtchinnikov [17] }\end{array}$ & No & Performance on political contributions & Contributing firms enjoy higher returns \\
\hline $\begin{array}{l}\text { Goldman, } \\
\text { Rocholl, and So [5] }\end{array}$ & Yes & $\begin{array}{l}\text { 1: Returns following announcement of } \\
\text { a politically connected person's nomination } \\
\text { to the board. 2: Returns following republican } \\
\text { win in } 2000 \text { presidential elections. }\end{array}$ & $\begin{array}{l}\text { Positive for study one. In study two, } \\
\text { positive for companies connected to } \\
\text { winning party, and negative for } \\
\text { those connected to losing party. }\end{array}$ \\
\hline $\begin{array}{l}\text { Bunkanwanicha and } \\
\text { Wiwattanakantang }[1]\end{array}$ & Yes & $\begin{array}{l}\text { Compare returns BHAR for } 1 \text { year before } \\
\text { election with BHAR for } 1 / 2 / 3 \text { years after elections }\end{array}$ & Positive \\
\hline $\begin{array}{l}\text { Claessens, Feijen, } \\
\text { and Laeven [2] }\end{array}$ & Yes & $\begin{array}{l}\text { CAR of } 20 \text { day around election results. } \\
\text { Correlation between donation to winning } \\
\text { and losing candidates is } 0.78 \text {. }\end{array}$ & $\begin{array}{l}\text { Positive effect for donation to } \\
\text { winning candidates, none for losing. }\end{array}$ \\
\hline Faccio $[3]$ & Yes & $\begin{array}{l}\text { Abnormal returns after board appointment } \\
\text { of politician and businessman entering politics. }\end{array}$ & $\begin{array}{l}\text { No effect of board appointments of } \\
\text { politicians. Positive for } \\
\text { businessman entering politics. }\end{array}$ \\
\hline $\begin{array}{l}\text { Hillman, Zardkoohi, } \\
\text { and Bierman [6] }\end{array}$ & Yes & Firm ex-employee to political office & Positive \\
\hline Jayachandran [7] & Yes & Tilt of control in senate & $\begin{array}{l}\text { Positive for connections to winning } \\
\text { party, negative for the counterparts. }\end{array}$ \\
\hline Fishman 2001 & Yes & Reaction to news of President Suharto's ill health. & $\begin{array}{c}\text { Positive } \\
\text { (firm value decreased on news of ill health). }\end{array}$ \\
\hline
\end{tabular}

for positive results of CPA on firm performance? I argue this may be the case, and point out an implicit assumption of event study methodology being violated in these studies, rendering these findings tautological. This exposition would lend further support to the increasing belief in literature that CPA does not improve firm performance [11] [17].

The next section introduces event study methodology, followed by the description of implicit assumption being violated in these studies. Nextis discussion of specific event studies that have violated this assumption studies which do not suffer from this problem. The final section concludes the discussion.

\section{The Implicit Assumption in Event Studies}

\subsection{The Event Study Method}

Event study methodology axiomatically assumes that stock price of a firm at any 
time reflects at least all publicly available information. Thus stock price at time $t$, $P_{t}$ reflects all information available at time $t$. If an event happens at time $t+1$, then $P_{t+1}$ reflects this new information. $P_{t+1}-P_{t}$ gives a measure of the magnitude of economic impact of the event on the firm. However, in practice, it is necessary to control for other events which may affect the stock prices. This is done by calculating abnormal increase in stock price over and above, for example, the increase expected from change in industry or market indices. Further the abnormal increase is measured using an event window beginning several days before the event and ending several days or weeks after the event to allow for information leakage and to allow the market to react to the news fully. If the abnormal increase is statistically more than zero, then the event can be said to have a positive effect on firm's value. Similarly if there is a statistically significant decrease in stock price, then the event can be said to have a negative effect on firm's value. A measure of increase or decrease can also provide an estimate of magnitude of impact of an event on firm value.

This method makes it possible to measure economic impact of events which would otherwise be extremely difficult or impossible. For example, Agrawal \& Kamakura [18] measured the stock prices movement of firms following announcements of celebrity endorsement contracts to find that such celebrity endorsements are indeed seen to add value to firms using this form of advertising.

\subsection{The Implicit Assumption}

Any event may be decomposed into two components: the cost component and the benefit component. For example, in the case of celebrity endorsements, the celebrities charge their fees for agreeing to endorse for a firm, and the firm gains from such endorsement by way of increased sales or better pricing power. The event studies measuring the magnitude of impact assume that the complete phenomenon occurs in the event window, i.e. the probability of celebrity endorsement changed from 0 to 1 in the event window. Event studies interested in measuring the sign of impact(positive or negative) carry a more relaxed assumption that the information generated by the event is such that there is perfect positive dependence in cost and benefit components i.e. the change in probabilities of both the components in the event window is equal.

A mathematical proof of these claims is given in Appendix A. However, it can be explained by way of an example, without resorting to mathematics. Suppose a firm participates in a lucky draw contest-let us call it contest A-in which 9 other firms (total 10) are participating, by paying $\$ 100$ which, if it wins, would get $\$ 900$. Clearly the expected return from contest $A$ is- $\$ 10$. When this decision of the participating firms is announced, they lose $\$ 10$ each in market value. An event study on announcement of this decision-let is called it event study A1-would produce the correct result that participating in contest A is financially a bad decision.

Now let us see what happens on the day of declaration of the winner of the draw. An event study on the day of this announcement-let us call it event study 
A2-would reveal that the firm value of the winner has increased by $\$ 810$ (prize amount - participation fee + the earlier decrease). However, to infer from such a stock price increase that participating in contest A is a sound business proposition is incorrect. This event only increased the benefit component of a decision taken and paid for earlier.

Another event study including both winners and losers-let us call it event study A3-would find a neutral effect of event on firm value as the winner gains $\$ 810$ and the other firms combined lose $\$ 810(90 \times 9)$.

Next, consider an event study-let us call it event study A4-with event window beginning just before announcement of the decision to participate in contest $\mathrm{A}$ and event window ending just after announcement of result would produce the correct result. In this event study, the winner's market value would be up by $\$ 800$ and the 9 other firms would each lose $\$ 100$ leading to a net negative change of $\$ 100$ in all 10 firms combined.

Event studies A2 and A3 are wrong because only the benefit component changed while the costs were already factored in in stock price of these firms. Event study A4 produces correct result because the entire phenomenon is completed in the event window. Event study A1 is correct as it changed expectations about cost and benefit by the same degree.

Now let us suppose that another lucky draw contest-contest B-is being held, in which 10 firms are participating by paying $\$ 100$ each, and the winner will take away $\$ 1100$. Clearly the expected return from contest B is $\$ 10$. When this decision of the participating firms is announced, they gain $\$ 10$ each in market value. An event study on announcement of this decision-let us call it event study A2-would produce the correct result that participating in contest B is financially a good decision.

Now let us see what happens on the day of declaration the winner of the draw. An event study on the day of this announcement-let us call it event study B2-would reveal that the firm values of the losing firms have decreased by $\$ 110$ (participation fee + the earlier increase). However to infer from such a stock price decrease that participating in contest $B$ is an unsound business proposition is incorrect. This event only changed the benefit component of a decision taken and paid for earlier.

Another event study including both winners and losers-let call it event study B3-would find a neutral effect of event on firm value as the winner gains $\$ 990$ and the other firms combined lose $\$ 990(110 \times 9)$.

Next consider an event study-let us call it event study B4-with event window beginning just before announcement of the decision to participate in contest $\mathrm{B}$ and event window ending just after announcement of the result would produce the correct result. In this event study, the winner's market value would be up by $\$ 1000$ and the 9 other firms would each lose $\$ 100$ leading to a net positive change of $\$ 100$ in all 10 firms combined.

Again, event studies B2 and B3 are wrong because only the benefit component changed while the costs were already factored in the stock price of these firms. 
Event study B4 produces correct result because the entire phenomenon is completed in the event window. Event study B1 is correct as it changed expectations about cost and benefit by the same degree.

The error in the two instances is straightforward. It seems absurd that any respected journal article would make this big a mistake in using event study method. However, I draw parallels to this example in event studies in corporate political activity in next section to demonstrate that this indeed is the case.

\section{Implications for Corporate Political Activity Event Studies}

\subsection{The Nature of Political Connections of Firms}

Corporate political activity studies examine the effect of exchange of favors between firms and politicians on firm performance. A firm may supply a politician with political contributions, soft contributions such as letting the politician access firm's aircraft, or take decision which serve the politician such as setting a plant in the politician's constituency and not downsizing during an election even if these decisions are economically harmful to the firm [19] [20]. All these are costs to the firm. The politician may supply a firm with reduced tax, license to operate, reduced competition by creating entries to barrier, bailout during financial distress, and so on [21] [22]. These are benefits to the firm in exchange of the costs.

This exchange of favors does not occur in an arm's length fashion as would take place in a marketplace due to the often illegal and illegitimate nature of such quid pro quo [23] [24]. A relationship of trust develops between the politician and the firm over time. Firms need to keep supporting connected politician even when the politician may not be in power temporarily to maintain the relationship. Therefore, the firm needs to keep incurring at least some costs even when the connected politician is no longer in a position to make favors to the firm. This strengthens the bond and the firm expects to receive favors when the politician is in power [25].

This is similar to the decision to participate in contests described earlier. The costs must be borne to get the benefits. The benefits depend on the ability of the connected politician to deliver favors. The ability of politicians to deliver favors depends on future events such as whether they win or lose future elections, or the party they are connected to comes to power or not, and so on. The question at hand is whether this is like contest A or like contest B, that is, do firms on an average gain from political connections in the long run (contest $B$ ) or do they lose from political connections in the long run (contest A)?

\subsection{Implications}

The event studies discussed here are presented in Table 1. Events related to corporate political activities can be broadly categorized into two types: events which change the political power of a connected person, and events which establish a political connection. 


\section{Events Changing the Political Power of Connected Person}

Studies of events affecting political fortunes of persons connected to firms include study of elections results [1] [2] [5], sudden change in party in power [7], ex-employee receiving a political office [6], businessman joining political party [3], and ill health of a politician making him less powerful [4]. Here a political connection already exists and the event only changes the potential benefits a connected firm may derive. These firms have already spent money in establishing the connection. The firms connected to persons whose power increases have greater chances of getting favors while incurring the same costs as before. This is similar to winning in the lucky draw contests described earlier. Studying firms connected to persons whose power increased due to the event is similar to event study A2. Such an event study cannot be used to draw any conclusion at all about the net effect of political connections. Similarly, firms connected to the politician or parties losing the election have lower chances of getting favors while incurring the same costs. This is similar to event study B2.Event studies which look at both winners and losers are making a mistake similar to event studies A3 and B3. Even these event studies do not lead to correct inference regarding the effect of political connections on firm value. Since for one groupfirms connected to winning politician or party-the expected benefits have gone up, and have come down for the other group-firms connected to losing politician or party - at the same level of costs, the two groups must demonstrates positive and negative effect of this event on firm value. This is exactly what these studies have found, that is, positive effect on firms connected to winning party or politician and negative effect on firms connected to losing party or politician. This no way implies that CPA is beneficial or detrimental to a firm. No conclusion in this regard can be made using these event studies.

\section{Events Creating a Political Connection}

The only event in the studies in Table 1 which creates a political connection is appointment of a politician on firm board. If we assume that creation of such a connection is costless-no money was spent prior to the politician agreeing to come on firm board-then this event is amenable to event study. The market would factor in all the costs and benefits of such an appointment and react accordingly. This is similar to event study on the day of decision to enter in contest A or event study on the day of decision to enter in contest B. It would produce correct result. However, evidence in these event studies is mixed. While Goldman et al. [5] find a positive effect of board appointment of politician in the context of United States, Faccio [3] found no effect in a sample spanning 47 countries.

\section{Conclusions}

In this note, I pointed out that most event studies on political connections have tested the stock price reactions to events which increase or decrease the power of a politically connected actor. Given that prior literature has strongly suggested 
that political connections are long term and firms need to spend money to maintain these connections even when the connected person is not in a position to return favors, study of such events is bound to produce a positive result for events which increase the power of connection, and negative for events which decrease power of connection. These studies are tautological and do not test the intended question of whether political connections add value to a firm. This is similar to saying that winning a lottery is beneficial and losing it is harmful while the real question is whether playing lottery is financially sound or not.

However studies of events which inform about establishment of political connections do not suffer from this problem. Such events are difficult to come by. Announcement of board appointment of politicians is the only such event which has been studied. Students of corporate political activity need to find more such events for robust estimation of the effect of political connections on firm value.

Literature reviews and meta-analyses on CPA need take cognizance of this critique while arriving at a conclusion about the net effect of CPA on firm performance. Such an inclusion would easily lead to the conclusion that political connections do not add net positive value to firm.

Thus this paper contributes to literature by defining events amenable to event study in further detail. This will help refine future event studies.

\section{Funding Statement}

No specific funding was received for this study. No conflict of interest exists.

\section{Conflict of Interest Statement}

The author declares no conflict of interest, financial or otherwise, exists with respect to this manuscript.

\section{References}

[1] Bunkanwanicha, P. and Wiwattanakantang, Y. (2009) Big Business Owners in Politics. Review of Financial Studies, 22, 2133-2168. https://doi.org/10.1093/rfs/hhn083

[2] Claessens, S., Feijen, E. and Laeven, L. (2008) Political Connections and Preferential Access to Finance: The Role of Campaign Contributions. Journal of Financial Economics, 88, 554-580. https://doi.org/10.1016/j.jfineco.2006.11.003

[3] Faccio, M. (2006) Politically Connected Firms. The American Economic Review, 96, 369-386. https://doi.org/10.1257/000282806776157704

[4] Fisman, R. (2001) Estimating the Value of Political Connections. The American Economic Review, 91, 1095-1102. https://doi.org/10.1257/aer.91.4.1095

[5] Goldman, E., Rocholl, J. and So, J. (2009) Do Politically Connected Boards Affect Firm Value? Review of Financial Studies, 22, 2331-2360. https://doi.org/10.1093/rfs/hhn088

[6] Hillman, A.J., Zardkoohi, A. and Bierman, L. (1999) Corporate Political Strategies and Firm Performance: Indications of Firm-Specific Benefits from Personal Service in the U.S. Government. Strategic Management Journal, 20, 67-81. https://doi.org/10.1002/(SICI)1097-0266(199901)20:1<67::AID-SMJ22>3.0.CO;2-T

[7] Jayachandran, S. (2006) The Jeffords Effect. Journal of Law and Economics, 49, $397-$ 
425. https://doi.org/10.1086/501091

[8] Aggarwal, R.K., Meschke, F. and Wang, T.Y. (2012) Corporate Political Donations: Investment or Agency? : Business and Politics. Business and Politics, 14.

http://www.degruyter.com/dg/viewarticle/j\$002fbap.2012.14.issue-1\$002f1469-3569 $.1391 \$ 002 \mathrm{f} 1469-3569.1391 . \mathrm{xml}$ https://doi.org/10.1515/1469-3569.1391

[9] Ansolabehere, S., De Figueiredo, J.M. and Snyder Jr., J.M. (2003) Why Is There So Little Money in U.S. Politics? Journal of Economic Perspectives, 17, 105-130. https://doi.org/10.1257/089533003321164976

[10] Faccio, M. (2010) Differences between Politically Connected and Nonconnected Firms: A Cross-Country Analysis. Financial Management, 39, 905-927. https://doi.org/10.1111/j.1755-053X.2010.01099.x

[11] Hadani, M. and Schuler, D.A. (2013) In Search of El Dorado: The Elusive Financial Returns on Corporate Political Investments. Strategic Management Journal, 34, 165-181. https://doi.org/10.1002/smj.2006

[12] Hersch, P., Netter, J. and Pope, C. (2008). Do Campaign Contributions and Lobbying Expenditures by Firms Create "Political" Capital? Atlantic Economic Journal, 36, 395-405. https://doi.org/10.1007/s11293-008-9125-y

[13] Hillman, A.J. (2005) Politicians on the Board of Directors: Do Connections Affect the Bottom Line? Journal of Management, 31, 464-481. https://doi.org/10.1177/0149206304272187

[14] Okhmatovskiy, I. (2010) Performance Implications of Ties to the Government and SOEs: A Political Embeddedness Perspective. Journal of Management Studies, 47, 1020-1047. https://doi.org/10.1111/j.1467-6486.2009.00881.x

[15] Siegel, J. (2007) Contingent Political Capital and International Alliances: Evidence from South Korea. Administrative Science Quarterly, 52, 621-666. https://doi.org/10.2189/asqu.52.4.621

[16] Cooper, M.J., Gulen, H. and Ovtchinnikov, A.V. (2010) Corporate Political Contributions and Stock Returns. The Journal of Finance, 65, 687-724. https://doi.org/10.1111/j.1540-6261.2009.01548.x

[17] Hillman, A.J., Keim, G.D. and Schuler, D. (2004) Corporate Political Activity: A Review and Research Agenda. Journal of Management, 30, 837-857. https://doi.org/10.1016/j.jm.2004.06.003

[18] Agrawal, J. and Kamakura, W.A. (1995) The Economic Worth of Celebrity Endorsers: An Event Study Analysis. Journal of Marketing, 59, 56-62. https://doi.org/10.2307/1252119

[19] Bonardi, J.P. (2008) The Internal Limits to Firms' Nonmarket Activities. European Management Review, 5, 165-174. https://doi.org/10.1057/emr.2008.16

[20] Bonardi, J.P. and Urbiztondo, S. (2013) Asset Freezing, Corporate Political Resources and the Tullock Paradox. Business \& Politics, 15, 275-293. https://doi.org/10.1515/bap-2012-0034

[21] Bonardi, J.P., Holburn, G.L.F. and Bergh, R.G.V. (2006) Nonmarket Strategy Performance: Evidence from U.S. Electric Utilities. The Academy of Management Journal, 49, 1209-1228. https://doi.org/10.5465/AMJ.2006.23478676

[22] Faccio, M., Masulis, R.W. and Mcconnell, J.J. (2006) Political Connections and Corporate Bailouts. Journal of Finance, 61, 2597-2635. https://doi.org/10.1111/j.1540-6261.2006.01000.x

[23] Barley, S.R. (2007) Corporations, Democracy, and the Public Good. Journal of Management Inquiry, 16, 201-215. https://doi.org/10.1177/1056492607305891 
[24] Schuler, D.A. (2008) Peering in From Corporate Political Activity. Journal of Management Inquiry, 17, 162-167. https://doi.org/10.1177/1056492608316698

[25] Bonardi, J.P., Hillman, A.J. and Keim, G.D. (2005) The Attractiveness of Political Markets: Implications for Firm Strategy. The Academy of Management Review, 30, 397-413. https://doi.org/10.5465/AMR.2005.16387895 


\section{Appendix A: Modeling Event Study Method}

\section{Model I}

Let event e with a true effect of $V_{e}$ on firm value have a probability of taking place $p_{t=0, e}$ at time $t=0$, and $p_{t=1, e}$ at a later time $t=1$.

Since $p_{t=0, e}$ and $p_{t=1, e}$ are probabilities:

$$
0 \leq p_{t=0, e}, p_{t=1, e} \leq 1
$$

Further, let us consider only the non-trivial case of:

$$
\left|V_{e}\right|>0
$$

Event studies assume at least semi-strong form of market efficiency, that is, stock prices at any time reflect all publicly available information related to the stock. Thus, implied value $I V$ of event e at time $t$ is:

$$
I V_{t}=p_{t, e} \cdot V_{e}
$$

Thus the change in implied value between times $t=0$ and $t=1$ is:

$$
\Delta I V_{t=0 \rightarrow 1}=I V_{t=1}-I V_{t=0}=\left(p_{t=1, e}-p_{t=0, e}\right) \cdot V_{e}
$$

Event studies measure this change in implied value. This immediately leads to lemma 1.

Lemma 1: Event studies correctly estimate magnitude of impact of an event if and only if the event occurs completely unexpectedly, that is, probability of event changes from 0 to 1 in the event window.

Proof: Mathematically, lemma 1 states $\Delta I V_{t=0 \rightarrow 1}=V_{e}$ iff $p_{t=1, e}=1$ and $p_{t=0, e}=0$.

Given $p_{t=1, e}=1$, and $p_{t=0, e}=0$.

Using (1.3),

$$
\Delta I V_{t=0 \rightarrow 1}=(1-0) \cdot V_{e}=V_{e}
$$

Conversely, if

$$
\Delta I V_{t=0 \rightarrow 1}=V_{e}
$$

However, from (1.3),

$$
\Delta I V=\left(p_{t=1, e}-p_{t=0, e}\right) \cdot V_{e}
$$

Equating values of $\Delta I V$

$$
V_{e}=\left(p_{t=1, e}-p_{t=0, e}\right) \cdot V_{e}
$$

or $1=p_{t=1, e}-p_{t=0, e} \quad$ [From (1.2) $V_{e}$ is non-zero]

Since $0 \leq p_{t=1, e}, p_{t=0, e} \leq 1$ [from (1.1)]

Therefore $p_{t=1, e}=1$ and $p_{t=0, e}=0$.

This completes the proof.

However, to infer from these equations that event study may be applied only on completed and completely unexpected events would be an extreme position. This is because economists are not always interested in estimating the magnitude of impact. They are often interested in estimating the sign of impact, that is, whether an event has an overall positive or negative impact on firm value. This 
can be accomplished by studying any event which changes the probability as shown in lemma 2.

Lemma 2: Event studies correctly estimate the sign of impact of an event when the probability of event taking place changes.

Proof: For Lemma 2 to be true, increase (decrease) in probability of an event with positive true impact must increase (decrease) the implied value. Similarly decrease (increase) in probability of an event with negative true impact must increase (decrease) the implied value. Mathematically, it can be expressed in the following four claims:

Claim 1: $\Delta I V_{t=0 \rightarrow 1}>0$ for $V_{e}>0$ and $p_{t=0, e}<p_{t=1, e}$

Proof of Claim 1:

Given $p_{t=0, e}<p_{t=1, e}$

$$
p_{t=1, e}-p_{t=0, e}>0
$$

Moreover given $V_{e}>0$

Therefore $\left(p_{t=1, e}-p_{t=0, e}\right) \cdot V_{e}>0$ [product of two positive numbers is always positive]

However, from (1.3)

$$
\Delta I V_{t=0 \rightarrow 1}=\left(p_{t=1, e}-p_{t=0, e}\right) \cdot V_{e}
$$

Therefore $\Delta I V_{t=0 \rightarrow 1}>0$

Claim 2: $\Delta I V_{t=0 \rightarrow 1}>0$ for $V_{e}<0$ and $p_{t=0, e}>p_{t=1, e}$

Proof of Claim 2:

Given $p_{t=0, e}>p_{t=1, e}$

$$
p_{t=1, e}-p_{t=0, e}<0
$$

Moreover given $V_{e}<0$

Therefore $\left(p_{t=1, e}-p_{t=0, e}\right) \cdot V_{e}>0$ [product of two negative numbers is positive]

However, from (1.3)

$$
\Delta I V_{t=0 \rightarrow 1}=\left(p_{t=1, e}-p_{t=0, e}\right) \cdot V_{e}
$$

Therefore $\Delta I V_{t=0 \rightarrow 1}>0$

Claim 3: $\Delta I V_{t=0 \rightarrow 1}<0$ for $V_{e}>0$ and $p_{t=0, e}>p_{t=1, e}$

Proof of Claim 3:

Since $p_{t=0, e}>p_{t=1, e}$

$$
p_{t=1, e}-p_{t=0, e}<0
$$

Also since $V_{e}>0$

Therefore $\left(p_{t=1, e}-p_{t=0, e}\right) \cdot V_{e}<0$ [product of a positive number and negative number is negative]

However, from (1.3)

$$
\Delta I V_{t=0 \rightarrow 1}=\left(p_{t=1, e}-p_{t=0, e}\right) \cdot V_{e}
$$

Therefore $\Delta I V_{t=0 \rightarrow 1}<0$

Claim 4: $\Delta I V_{t=0 \rightarrow 1}<0$ for $V_{e}<0$ and $p_{t=0, e}<p_{t=1, e}$ 
Proof of Claim 4:

When $p_{t=0, e}<p_{t=1, e}$

$$
p_{t=1, e}-p_{t=0, e}>0
$$

And $V_{e}<0$

Therefore $\left(p_{t=1, e}-p_{t=0, e}\right) \cdot V_{e}<0$ [product of a positive number and negative number is negative]

However From (1.3)

$$
\Delta I V_{t=0 \rightarrow 1}=\left(p_{t=1, e}-p_{t=0, e}\right) \cdot V_{e}
$$

Therefore $\Delta I V_{t=0 \rightarrow 1}<0$

This model may lead us to believe that event study may be applied to incomplete events for finding the direction of impact of event on firm value. However this involves an unarticulated assumption as demonstrated below in Model II.

\section{Model II}

Any event can be assumed to have two components: the benefits and costs associated with an event. Thus, value associated with an event $e$ is the benefits minus costs.

$$
V_{e}=B_{e}-C_{e}
$$

The two components may not independent of each other; however, they may not be perfectly positively dependent either. It is possible that the probability of incurring costs is more than getting benefits at some point of time or vice versa. In such a case the implied value at any time $t$ would be as follows.

$$
I V_{t}=p_{t, B_{e}} \cdot B_{e}-p_{t, C_{e}} \cdot C_{e}
$$

Also change in $I V$ between times $t=0$ and $t=1$ is:

$$
\begin{aligned}
\Delta I V_{t=0 \rightarrow 1} & =I V_{t=1}-I V_{t=0} \\
& =p_{t=1, B_{e}} \cdot B_{e}-p_{t=1, C_{e}} \cdot C_{e}-\left(p_{t=0, B_{e}} \cdot B_{e}-p_{t=0, C_{e}} \cdot C_{e}\right) \\
& =\left(p_{t=1, B_{e}}-p_{t=0, B_{e}}\right) \cdot B_{e}-\left(p_{t=1, C_{e}}-p_{t=0, C_{e}}\right) \cdot C_{e}
\end{aligned}
$$

Since $p_{t, B_{e}}$ and $p_{t, C_{e}}$ are probabilities:

$$
0 \leq p_{t, B_{e}}, p_{t, C_{e}} \leq 1
$$

Further, let us consider only the non-trivial case of

$$
\left|V_{e}\right|, B_{e}, C_{e}>0
$$

Lemma 1 still holds with this model as shown next.

Lemma 1: Event studies correctly estimate magnitude of impact of an event if and only if the event occurs completely unexpected, that is, probability of event changes from 0 to 1 .

Proof: Mathematically, $\Delta I V_{t=0 \rightarrow 1}=V_{e}$ if

$$
p_{t=0, B_{e}}=p_{t=0, C_{e}}=0 \text { and } p_{t=1, B_{e}}=p_{t=1, C_{e}}=1
$$

From (2.2)

$$
\Delta I V_{t=0 \rightarrow 1}=\left(p_{t=1, B_{e}}-p_{t=0, B_{e}}\right) \cdot B_{e}-\left(p_{t=1, C_{e}}-p_{t=0, C_{e}}\right) \cdot C_{e}
$$




$$
\begin{aligned}
& \text { If } p_{t=0, B_{e}}=p_{t=0, C_{e}}=0 \text { and } p_{t=1, B_{e}}=p_{t=1, C_{e}}=1 \text {. } \\
& \Delta I V_{t=0 \rightarrow 1}=B_{e}-C_{e}=V_{e}
\end{aligned}
$$

Conversely, if $\Delta I V_{t=0 \rightarrow 1}=V_{e}$

However, from (2.2) and (2.1)

$$
\left(p_{t=1, B_{e}}-p_{t=0, B_{e}}\right) \cdot B_{e}-\left(p_{t=1, C_{e}}-p_{t=0, C_{e}}\right) \cdot C_{e}=B_{e}-C_{e}
$$

This implies

$$
p_{t=1, B_{e}}-p_{t=0, B_{e}}=1
$$

and

$$
p_{t=1, C_{e}}-p_{t=0, C_{e}}=1
$$

Since, $0 \leq p_{t=1, B_{e}}, p_{t=0, B_{e}}, p_{t=1, C_{e}}, p_{t=0, C_{e}} \leq 1 \quad$ [from (2.3)]

Therefore, $p_{t=1, B_{e}}=1$, and $p_{t=1, B_{e}}=0$ and $p_{t=1, C_{e}}=1$, and $p_{t=0, C_{e}}=0$

Hence the event study correctly captures the magnitude of impact.

The case of incomplete event is interesting. Unlike the aforementioned lemma 2 , it is possible that a partially expected event produces a wrong sign if the change in event probabilities of $B_{e}$ and $C_{e}$ is not equal.

Theorem 1: Event study may incorrectly measure the sign of economic impact of an event only if the change in probability of the components of benefits and costs is not equal.

Proof:

The theorem statement can be broken down into three simpler parts, and let us prove each separately. These three parts taken as a whole establish Theorem 1.

Theorem 1A: Event study correctly measures the sign of economic impact of an event if the change in probability of the components of benefits and costs is equal.

Proof: Let $p_{t=1, B_{e}}-p_{t=0, B_{e}}=p_{t=1, C_{e}}-p_{t=0, C_{e}}=p$

Since,

$$
\begin{aligned}
\Delta I V_{t=0 \rightarrow 1} & =\left(p_{t=1, B_{e}}-p_{t=0, B_{e}}\right) \cdot B_{e}-\left(p_{t=1, C_{e}}-p_{t=0, C_{e}}\right) \cdot C_{e} \\
& =p \cdot B_{e}-p \cdot C_{e}=p \cdot\left(B_{e}-C_{e}\right)=p \cdot V_{e}
\end{aligned}
$$

This reduces to lemma 2 already proved.

Theorem 1B: There exists at least one case when event study incorrectly measures the sign of economic impact of an event if the change in probability of the components of benefits and costs is not equal.

Proof:

Let, without loss of generality, $B_{e}=r \cdot C_{e}$ for all positive real numbers $r$.

Therefore, $V_{e}=B_{e}-C_{e}=(r-1) \cdot C_{e}$

Further, let $\left(p_{t=1, B_{e}}-p_{t=0, B_{e}}\right)=s *\left(p_{t=1, C_{e}}-p_{t=0, C_{e}}\right)=s * p$ for all $s$ as real numbers

Since

$$
\Delta I V_{t=0 \rightarrow 1}=\left(p_{t=1, B_{e}}-p_{t=0, B_{e}}\right) \cdot B_{e}-\left(p_{t=1, C_{e}}-p_{t=0, C_{e}}\right) \cdot C_{e}
$$

Or 


$$
\Delta I V_{t=0 \rightarrow 1}=s \cdot p \cdot B_{e}-p \cdot C_{e}=s \cdot p \cdot r \cdot C_{e}-p \cdot C_{e}=p \cdot C_{e}(s r-1)
$$

Now for all $r>1$ and $s$ such that $s r<1 ; V_{e}>0$ and $\quad \Delta I V_{t=0 \rightarrow 1}<0$

And for all $r<1$ and $s$ such that $s r>1 ; V_{e}<0$ and $\Delta I V_{t=0 \rightarrow 1}>0$.

Theorem 1C: There exists a case when event study correctly measures the sign of economic impact of an event if the change in probability of the components of benefits and costs is not equal.

In the above proof, for all $r>1$ and $s r>1 ; V_{e}>0$ and $\Delta I V_{t=0 \rightarrow 1}>0$

And for all $r<1$ and $s r<1 ; V_{e}<0$ and $\Delta I V_{t=0 \rightarrow 1}<0$.

Thus, when the benefit component increases more than the cost component, an otherwise negative impact event may be incorrectly inferred to have positive net impact and vice versa.

\section{Scientific Research Publishing}

Submit or recommend next manuscript to SCIRP and we will provide best service for you:

Accepting pre-submission inquiries through Email, Facebook, LinkedIn, Twitter, etc. A wide selection of journals (inclusive of 9 subjects, more than 200 journals)

Providing 24-hour high-quality service

User-friendly online submission system

Fair and swift peer-review system

Efficient typesetting and proofreading procedure

Display of the result of downloads and visits, as well as the number of cited articles Maximum dissemination of your research work

Submit your manuscript at: http://papersubmission.scirp.org/

Or contact tel@scirp.org 